No $2010-02$

February

CEPII

CENTRE

D'ÉTUDES PROSPECTIVES

ET D'INFORMATIONS

INTERNATIONALES

Estimation of consistent multi-country FEERs

Benjamin Carton and Karine Hervé 


\section{TABLE OF CONTENTS}

Non-technical summary. . . . . . . . . . . . . . . . . . . . . . . . . . . 3

Abstract . . . . . . . . . . . . . . . . . . . . . . . . . . 3

Résumé non technique . . . . . . . . . . . . . . . . . . . . . . . . . . . 4

Résumé court . . . . . . . . . . . . . . . . . . . . . . . . . . . 5

1. Introduction . . . . . . . . . . . . . . . . . . . . . . . . . . . . . . 6

2. The consistency of the trade model at the global level . . . . . . . . . . . . . 7

2.1. Constraints that ensure global consistency . . . . . . . . . . . . . . . . 8

2.2. Constraints that ensure the consistency in value . . . . . . . . . . . . . . 9

2.3. Constraints that ensure the consistency in volume . . . . . . . . . . . . . 10

3. The equilibrium exchange rate model . . . . . . . . . . . . . . . . . . . . 12

4. The over identification problem with $\mathrm{N}$ countries . . . . . . . . . . . . . . . 14

4.1. Ignoring one zone's equilibrium . . . . . . . . . . . . . . . . . . . . 15

4.2. Sharing out between all zones the inconsistency of the targets. . . . . . . . . 16

5. FEER for 19 industrialised and emerging countries . . . . . . . . . . . . . . 19

5.1. Trade parameters and other structural data . . . . . . . . . . . . . . . . 19

5.2. Equilibrium exchange rates . . . . . . . . . . . . . . . . . . . . . 21

6. Conclusion . . . . . . . . . . . . . . . . . . . . . . . . . . . . . . 23

Bibliography . . . . . . . . . . . . . . . . . . . . . . . . 24

Appendix . . . . . . . . . . . . . . . . . . . . . . . . . . . . . . 26 


\title{
ESTIMATION OF CONSISTENT MULTI-COUNTRY FEERS
}

\section{NON-TECHNICAL SUMMARY}

For years, the growing global imbalances between developed Anglo-Saxon countries and emerging Asian and oil-producing countries have motivated a large literature both dealing with causes and consequences. One of the most important issues is the threat of strong currency realignments, particularly for the dollar. Since the beginning of the economic crisis at the end of 2008, practitioners have wondered whether the ongoing process was going to close the imbalances and reduce the misalignment of the dollar or not.

In order to discuss this point, we develop a worldwide consistent fundamental equilibrium exchange rate (FEER) model. Methodological issues are important when estimating in the same model consistent equilibrium exchange rates for $N$ countries or areas covering the whole world. First, the trade model has to be balanced at the aggregate level. This paper proposes a new method to achieve this both in volume and in value. Second, the $N-1$ independent bilateral exchange rates cannot ensure that the $N$ areas will reach their macroeconomic equilibrium. This paper examines the existing solutions to solve the $N-1$ problem and proposes an alternative one which minimizes the distance to the current-account targets.

The recent economic crisis has strongly modified the assessment on output gap in many areas, namely in the US. Thus the dollar appears less overvalued than in previous estimations and the euro more overvalued. Despite the economic crisis, we observe no sign of a reduction in imbalances in Asian countries.

\begin{abstract}
Most studies on equilibrium exchange rates focus on a limited number of G7 countries. But in a situation of world imbalances, emerging countries can no longer be excluded. The study of all equilibrium exchange rates is delicate. First, the trade model has to be balanced at the aggregate level. This paper suggests a method to achieve world balance both in volume and in value. Second, the $N-1$ bilateral exchange rates cannot ensure that the $N$ areas will reach their macroeconomic equilibrium simultaneously. This paper examines the existing solutions to solve the $N-1$ problem and proposes an alternative which minimizes the distance to the current-account targets. Finally, in order to compare the relevance of the different methodologies, FEERs are calculated for 19 industrialized and developing countries.
\end{abstract}

JEL Classification: F31, F32.

Keywords: $\quad$ Exchange Rates, Current Account Adjustment. 


\section{ESTIMATION DE TAUX DE CHANGE D'ÉQUILIBRE FONDAMENTAUX COHÉRENTS AU NIVEAU MONDIAL}

\section{RÉSUME NON TECHNIQUE}

Le taux de change d'équilibre fondamental (FEER), défini par Williamson (1985), est celui qui permet l'équilibre entre l'épargne nette et le solde courant à moyen terme, c'est-à-dire lorsque le PIB est à son potentiel. Cette définition du FEER a été utilisée à l'origine dans le cas de petites économies ouvertes (les pays de l'Union européenne). Depuis une dizaine d'années elle a été largement appliquée pour évaluer les variations de taux de change compatibles avec une résorption des déséquilibres mondiaux. L'extension d'un modèle comprenant un seul pays à un modèle mondial cohérent, construit à partir des équations du commerce extérieur, pose trois difficultés principales : (i) les équations de commerce, définies pour chaque pays, ne conduisent pas automatiquement à un équilibre au niveau mondial ; (ii) selon la manière dont elles sont estimées, les cibles de balance courante (les flux nets de capitaux compatibles avec un modèle de croissance équilibrée) des différents pays ne sont pas nécessairement compatibles au niveau mondial ; (iii) les $N-1$ taux de change bilatéraux indépendants ne peuvent assurer l'équilibre épargneinvestissement de $N$ pays (le problème de surdétermination).

Dans le cas d'une économie fermée, l'équilibre épargne-investissement à moyen terme est assuré par le taux d'intérêt. Transposé à l'économie mondiale, ceci permet de résoudre les deux dernières difficultés : les cibles de balance courante étant dépendantes du taux d'intérêt mondial, elles sont compatibles entre elles dès lors que l'équilibre épargne-investissement au niveau mondial est assuré; l'introduction dans le modèle du taux d'intérêt mondial en tant que variable endogène supplémentaire élimine le problème de surdétermination. Bien sûr, l'évaluation du taux de change d'équilibre d'un petit pays peut se passer d'un modèle comportant explicitement le taux d'intérêt mondial. En généralisant ce cas particulier à un grand nombre de pays, les méthodes d'évaluation employées en pratique ne l'ont pas réintégré mais ont eu recours à un certain nombre de méthodes plus ou moins $a d$ hoc. L'une d'entre-elles consiste à ignorer l'équilibre macroéconomique d'une des zones du modèle (il y a alors autant de variables endogènes que d'équations). Cependant les estimations de taux de change d'équilibre diffèrent, parfois de beaucoup, selon la zone ignorée. Certains auteurs ont alors développé d'autres méthodes : celles-ci permettent de s'approcher de l'équilibre de chacune des zones mais elle ne l'atteignent jamais exactement. Cet article discute les principales méthodes pratiques visant à résoudre le problème de la surdétermination et propose une méthode inédite qui apporte une solution plus équilibrée à ce problème. Le principe directeur en est très simple : il s'agit de minimiser la distance entre les cibles de balance courante ex ante et les balances courantes ex post compatibles avec les taux de change d'équilibre estimés.

Alors que le problème de la surdétermination a été largement étudié, celui de la cohérence comptable du modèle de commerce sous-jacent à l'estimation des taux de change l'a peu été. Nous proposons dans cet article une méthode originale pour assurer la cohérence comptable en volume et en valeur du modèle de commerce. Il s'agit d'imposer une contrainte sur les élasticités-prix des équations d'exportations. Cette contrainte est très intuitive : face à une variation des taux de change bilatéraux, les parts de marché des 
différents pays doivent évoluer de façon cohérente afin que leur somme soit toujours égale à l'unité.

Notre méthodologie (traitement de la surdétermination et équilibre comptable du commerce) est ensuite mise en œuvre dans un modèle où l'économie mondiale est découpée en 20 zones où sont isolées les principales économies développées et émergentes entre 2000 et 2008. L'estimation des taux de change d'équilibre se fait en deux temps : dans un premier temps les balances courantes sous-jacentes (i.e. corrigées de l'écart de production et de la courbe en J) sont estimées, ensuite les taux de change d'équilibre comblent l'écart entre les balances courantes sous-jacentes et les balances courantes « cibles ».

La crise économique de 2008-2009 a sensiblement modifié l'estimation des écarts de production et donc le niveau des balances courantes sous-jacentes. Ainsi, pour les États-Unis, celle-ci s'est améliorée entre 2001 et 2008 malgré une détérioration sévère de la balance courante observée. La surévaluation du dollar en 2008 apparait aujourd'hui moindre qu'elle n'apparaissait il y a deux ans. En miroir, la surévaluation de l'euro a plutôt tendance à se confirmer ces deux dernières années, tant en termes de taux de change effectif réel (près de 30\% en 2008) que de taux de change bilatéral par rapport au dollar (avec une parité d'équilibre autour de 1,30 USD). L'appréciation du yen depuis le début de la crise a rapproché la monnaie nippone de son niveau d'équilibre tant effectif réel que vis-à-vis du dollar. L'Inde et le Brésil auraient corrigé l'essentiel de leur sous-évaluation tandis que les pays asiatiques n'ont pas réellement amorcé leur ajustement.

Classification JEL : F31, F32.

Mots clés : $\quad$ Taux de change, ajustement de la balance courante.

\section{RÉSUMÉ COURT}

Les déséquilibres mondiaux des années 2000 rendent nécessaire d'intégrer un grand nombre de pays développés et émergents dans l'estimation de taux de change d'équilibre, ce qui pose un certain nombre de difficultés pratiques en particulier le bouclage du modèle de commerce et la surdétermination. Nous proposons une méthode originale afin que le modèle de commerce sous-jacent à l'estimation des taux de change soit équilibré au niveau mondial tant en volume qu'en valeur. Nous faisons une revue critique des méthodes visant à contourner le problème de surdétermination ( $N-1$ taux de change assurant l'équilibre de $N$ zones) et proposons une méthode consistant à minimiser l'écart des balances courantes à leur cible. Afin de comparer ces différentes méthodes, nous estimons le taux de change d'équilibre de 19 pays développés et émergents. 


\title{
ESTIMATION OF CONSISTENT MULTI-COUNTRY FEERs ${ }^{1}$
}

\author{
Benjamin Carton* and Karine Hervé ${ }^{\dagger}$
}

\section{INTRODUCTION}

The beginning of the 90's has seen a burgeoning literature on equilibrium exchange rate dealing with the choice of parities for the adoption of the common currency in Europe. Irrespective of the definition given to the equilibrium exchange rate, the approches in use generally consider a small open economy and a "large" rest of the world (RoW). In the case of the FEER (Fundamental Equilibrium Exchange Rate) model, the equilibrium exchange rate allows the current account of the small economy to reach a "target" level (saving-investment equilibrium) in the medium term (assuming internal equilibrium, i.e. closing domestic output gap). Given the small size of the economy, any target for its current account corresponds to a balanced current account of the RoW. So, whatever the effective exchange rate of the RoW vis-à-vis the small economy (which is, by construction, the opposite of the effective exchange rate of the small economy), its current account is balanced. In other words, the exchange rate contributes to the saving-investment equilibrium of the small economy, but not to the one of the RoW.

The growing global imbalances that appeared at the end of the 1990's have reshuffled the FEER literature and the basic model has been modified in order to consider simultaneously the equilibrium exchange rates of a large number of countries, representing the majority of the world economy. In this new framework, the assumption that the current account of the RoW is balanced for all possible levels of the exchange rates is no longer valid. This requires explicitly modeling the RoW, but also has two important consequences: the consistency of the trade model has to be ensured and the "overidentification problem" ( $N-1$ independant bilateral exchange rates have to ensure the saving-investment equilibrium of $N$ zones) has to be circumvented.

The FEER model assumes that the effects of the exchange rate on the current account can be reduced to the effects on the trade balance only. It is then based on traditional trade model which specifies the import and export volumes of each economy, including the RoW. The trade model has to be balanced both in value (current price) and in volume (constant price). Two main methods have been used to achieve these two conditions: the first one consists in not specifying the volumes of imports and exports of one of the zones and then deducting the respective values

\footnotetext{
${ }^{1}$ We thank Jean-Luc Schneider and Hervé Bonnaz for their support at an early stage of our work at the French Ministry of Finance. The views expressed in this paper are those of the authors and do not necessarily reflect those of CEPII and Banque de France.

*CEPII (benjamin.carton@ cepii.fr).

${ }^{\dagger}$ Banque de France (karine.herve@ banque-france.fr)
} 
as a residual. The second one estimates the volume of imports and exports separately for each economy and then distributes the net world exports across all zones. We propose a third method that consists in imposing constraints on the trade equations to ensure consistency.

Once the trade model is built, equilibrium exchange rates are those which allow every zone to reach its current-account target. However, the overidentification problem makes the task impossible ( $N-1$ instruments to reach $N$ objectives). The reason is straightforward: in a closed economy, the exchange rate does not play any role in the saving-investment equilibrium, so does the interest rate at least in the medium run. In the $N$ zones case, the world interest rate should be the $N^{\text {th }}$ endogenous variable allowing each economy to reach its balance. We do not follow this approach here. The alternative method proposed in this article, certainly less rigorous but simpler to implement, is inspired from Faruqee \& Isard (1998) and consists in getting as close as possible to the $N$ current-account targets with $N-1$ independent bilateral exchange rates (minimizing target gaps).

We apply this methodology (consistent trade model, minimizing target gaps) to estimate equilibrium exchange rates for 19 countries. Specifically, we consider six industrialized countries (the United States, Canada, Euro area, the United Kingdom, Australia / New Zealand, Japan), twelve emerging countries (China, India, Korea, Taiwan, Singapore, Hong-Kong, Malaysia, Thailand, Philippines, Indonesia, Mexico, Brazil) and the rest of the world.

The rest of the paper is structured as follows. Section 2 presents the model of international trade which is later used to calculate the equilibrium exchange rates; it focuses on the global consistency of trade, both in volume and in value. Section 3 develops the fundamental equilibrium exchange rate model. Section 4 deals specifically with the overidentification problem. It analyzes the various solutions put forward in the literature and proposes a new methodology that overcomes some problems of previous approaches. Finally, Section 5 discusses the empirical applications of the various approaches.

\section{THE CONSISTENCY OF THE TRADE MODEL AT THE GLOBAL LEVEL}

The FEER approach (Williamson, 1994) is based on a model of international trade in order to estimate the impact of exchange-rate changes on the various current accounts. Some consistency of the trade model is required: the sum of exports must equal the sum of imports both in volume (constant price) and in value (current price). But the specification of the trade model commonly used in the literature does not ensure consistency. Imports and exports of each zone depend on domestic and foreign demands as well as on relative prices. Even though the demand for exports is derived from the imports of the other countries, nothing ensures that the volumes of exports and imports are equal at the global level.

Several solutions can be proposed. The first one consists in not specifying the volumes of imports and exports of one of the zones and then deriving the respective values as a residual (generally, the chosen zone is the RoW). The second solution, which is often used in inter- 
national macro-econometric models, distributes the world excess or lack of exports across all exporters. This second solution is however not very convenient within the FEER framework. This paper suggests a third solution to the consistency problem. Specifically, we propose to impose constraints on price and demand elasticities of imports and exports, which ensure that, in the first order and in the neighborhood of the steady state, the world is balanced in both volumes and values.

\subsection{Constraints that ensure global consistency}

In the model presented bellow, we consider $N$ countries or zones. Each country produces a tradable good; tradable goods of different countries are imperfect substitutes. Moreover, it is assumed that the law of one price holds for these goods so that the price $P_{x, i}$ (in domestic currency unit) of the tradable goods of country $i$ does not depend on the destination country. The volume of exports from country $i$ to country $j$ is denoted $X_{i j}, E_{i}$ is the exchange rate of country $i$. The trade balance of country $i$, expressed in the international numeraire, is then given by:

$$
\mathrm{TB}_{i}=E_{i} P_{x, i} \sum_{j \neq i} X_{i j}-\sum_{j \neq i} P_{x, j} E_{j} X_{j i}
$$

Using bilateral flows in an empirical model to estimate the effect of exchange rates on the trade balance is not the strategy commonly used in the FEER literature: even though bilateral data exist at the product level, they are available for a short period of time; the estimation of bilateral flows equations needs to build on relevant relative price and relevant demand; beside, the share of variance explained is not expected to improve with bilateral data. ${ }^{2}$ So, Equation (1) is generally replaced by the following more simple equation:

$$
\mathrm{TB}_{i}=E_{i} P_{x, i} X_{i}-P_{m, i} M_{i}
$$

where $X_{i}$ and $M_{i}$ are the aggregate exports and imports in volume of country $i$ and $P_{m, i}$ the aggregate import price in international numeraire.

The change of the trade balance is a function of the relative changes in its import and export volumes as well as the changes in the nominal exchange rates or import and export prices.

$$
d \mathrm{~TB}_{i}=E_{i} P_{x, i} X_{i}\left(\frac{d E_{i}}{E_{i}}+\frac{d P_{x, i}}{P_{x, i}}+\frac{d X_{i}}{X_{i}}\right)-P_{m, i} M_{i}\left(\frac{d P_{m, i}}{P_{m, i}}+\frac{d M_{i}}{M_{i}}\right)
$$

\footnotetext{
${ }^{2}$ The volatility of destination-specific or product-specific volumes of trade is higher than the volatility of the aggregate volume of trade.
} 
The world trade balance (WTB) must be equal to zero for any exchange-rate change and for any change in import and export volumes, provided that these changes are compatible with the trade equations. ${ }^{3}$ Assuming that world trade data is consistent, this condition can be ensured as a first-order condition in the neighborhood of observed data.

$$
d \mathrm{WTB}=X^{\prime}\left(\hat{E}+\hat{P}_{x}+\hat{X}\right)-M^{\prime}\left(\hat{P}_{m}+\hat{M}\right)=0
$$

with $X^{\prime}=\left(E_{1} P_{x, 1} X_{1}, \ldots, E_{N} P_{x, N} X_{N}\right)$ and $M^{\prime}=\left(P_{m, 1} M_{1}, \ldots, P_{m, N} M_{N}\right)$ are the vectors of observed exports and imports in international numeraire, $\hat{X}=\frac{d X}{X}$ is the vector of relative variation of exports in volume (identical definition for $\hat{M}$ ) and $\hat{E}$ is the vector of relative variation of exchange rates (identical definition for $\hat{P}_{m}$ and $\left.\hat{P}_{x}\right) .{ }^{4}$ Separating the variations that are due to changes in prices $\left(d \mathrm{WTB}_{1}\right)$ from those that are due to changes in volumes $\left(d \mathrm{WTB}_{2}\right)$ gives:

$$
d \mathrm{WTB}=\underbrace{X^{\prime}\left(\hat{E}+\hat{P}_{x}\right)-M^{\prime} \hat{P}_{m}}_{d \mathrm{WTB}_{1}}+\underbrace{X^{\prime} \hat{X}-M^{\prime} \hat{M}}_{d \mathrm{WTB}_{2}}
$$

\subsection{Constraints that ensure the consistency in value}

Absent any change in trade volumes, a change in exchange rates or export prices has to be neutral on the world trade balance in value: any variation of the trade balance of a country must have its counterpart in the variation of the trade balance of others countries. This condition, called consistency in value, translates in the condition $d \mathrm{WTB}_{1}=0$. Assuming that there is no pricing-to-market (the price of exports does not depend on the destination), import price can be expressed as a log-weighted average of other countries' export prices:

$$
P_{m, i}=\prod_{j \neq i}\left(P_{x, j} E_{j}\right)^{\lambda_{i j}} \Rightarrow \hat{P}_{m}=P\left(\hat{E}+\hat{P}_{x}\right) \quad \text { with } \quad P=\left(\lambda_{i j}\right)
$$

For a given change in exchange rates $\hat{E}$ and export prices $\hat{P}_{x}$, the condition $d \mathrm{WTB}_{1}=0$ can be expressed as :

$$
d \mathrm{WTB}_{1}=\left(X^{\prime}-M^{\prime} P\right)\left(\hat{E}+\hat{P}_{x}\right)=0
$$

\footnotetext{
${ }^{3}$ It would be absurd to expect $d \mathrm{WTB}=0$ for any variations in imports and exports of a particular country. This condition has to hold only for imports and exports variations compatible with import and export equations (see Section 2.3).

${ }^{4}$ We follow a comparative static approach: volumes are evaluated at the observed prices and exchange rates, so volumes and values coincide for observed values. When one wonders what would have been trade flows if export prices and exchange rates had been different, the dichotomy value/volume reappears.
} 
Imposing $d \mathrm{WTB}_{1}=0$ for any change in exchange rates and export prices turns into a condition on matrix of weights $P$, which has to verify $X^{\prime}=M^{\prime} P$. A natural way to satisfy this constraint is to set $\lambda_{i j}$ equal to the share of country $j$ in the total value of imports of country $i$.

\subsection{Constraints that ensure the consistency in volume}

To derive the conditions of the consistency of the trade model at constant price, one has to specify the volume of imports and exports as a function of exogenous variables of the trade model. They are commonly assumed to depend on domestic and foreign demands as well as on the relative competitiveness of the economy $\left(\eta_{m}, \eta_{x}, \epsilon_{m}^{r}\right.$ and $\epsilon_{x}$ are positive parameters denoting elasticities of import and exports relative to relevant demand and price):

$$
\hat{M}_{i}=\eta_{m, i} \hat{Y}_{i}-\epsilon_{m, i}^{r}\left(\hat{P}_{m, i}-\hat{E}_{i}-\hat{P}_{i}\right)
$$

$$
\hat{X}_{i}=\eta_{x, i} \hat{Y}_{e, i}+\epsilon_{x, i} \hat{R}_{i}
$$

Where $Y_{i}$ is the output of country $i, P_{i}$ is the domestic price level, $Y_{e, i}$ is the world demand for country $i$ 's exports (it depends on imports of other countries), and $R_{i}$ represents the pricecompetitiveness of country $i$ on third markets (a variable with a hat denotes its relative variation). However, the reduced form of the import equation is inaccurate for small open economies as, for these countries engaged in processing trade, the volume of imports is mainly driven by the volume of exports. ${ }^{5}$ To take into account this characteristic, we assume that a share of domestic demand relies on non-tradable goods while exports entirely rely on tradable ones. Let $A_{i}=Y_{i}+M_{i}-X_{i}$ be the final domestic demand in country $i$. A share $\tau$ of this demand is automatically devoted to non-tradable goods, so the demand for tradable goods writes:

$$
T_{i}=X_{i}+(1-\tau) A_{i}=\tau X_{i}+(1-\tau) M_{i}+(1-\tau) Y_{i}
$$

In relative terms, the same equation writes:

$$
\hat{T}_{i}=\frac{\tau X_{i}}{X_{i}+(1-\tau) A_{i}} \hat{X}_{i}+\frac{(1-\tau) M_{i}}{X_{i}+(1-\tau) A_{i}} \hat{M}_{i}+\frac{(1-\tau) Y_{i}}{X_{i}+(1-\tau) A_{i}} \hat{Y}_{i}
$$

Demand for tradable goods splits between domestic and imported tradable goods, the share of imports depending on the relative price of imports. We replace the reduced form import

\footnotetext{
${ }^{5}$ Inaccuracy appears when evaluating the counterfactual trade balance corresponding to a closed output gap. It becomes critical just before the 2008 crisis.
} 
Equation (8) by a new import equation: ${ }^{6}$

$$
\hat{M}_{i}=\hat{T}_{i}-\epsilon_{m, i}\left(\hat{P}_{m, i}-\hat{E}_{i}-\hat{P}_{i}\right)
$$

To continue the calculus, it appears more convenient to consider all countries simultaneously and new notations need to be introduced. A variable deprived of its country-specific subscript denotes the vector for all countries; for $a$ a vector, $[a]$ denotes the matrix with $a$ on the diagonal and zero otherwise. Equation (11) rewrited for all countries becomes:

$$
\hat{M}=\left[\frac{\tau X}{X+(1-\tau) A}\right] \hat{X}+\left[\frac{(1-\tau) Y}{X+(1-\tau) A}\right] \hat{Y}+\left[\frac{(1-\tau) M}{X+(1-\tau) A}\right] \hat{M}-\left[\epsilon_{m}\right] P \hat{E}
$$

The competitiveness of country $i$ is calculated as a weighted average of all real bilateral exchange rates:

$$
R_{i}=\frac{\prod_{j \neq i}\left(P_{x j} E_{j}\right)^{\rho_{i j}}}{P_{x i} E_{i}} \Rightarrow \hat{R}=C \hat{E} \text { with } C=\left(\rho_{i j}\right)
$$

where $\rho_{i j}$ measures the level of competition between countries $i$ and $j$ on third markets.

The foreign demand for country $i$ 's exports is a weighted average of other countries' imports:

$$
Y_{e, i}=\prod_{j \neq i} M_{j}^{\theta_{i j}} \Rightarrow \hat{Y}_{e}=D \hat{M} \quad \text { with } \quad D=\left(\theta_{i j}\right)
$$

where $\theta_{i j}$ is the share of country $j$ in the exports of country $i$. The log-variation of exports in volume is given by:

$$
\hat{X}=\left[\eta_{x}\right] D \hat{M}+\left[\epsilon_{x}\right] C \hat{E}
$$

Given the form of imports and exports in volume (Equations (12) and (13)), the variation of world trade balance writes:

\footnotetext{
${ }^{6}$ In this new import equation, the demand term, $T$, includes import volume. This modifies the price-elasticity that appears in Equation (11).
} 


$$
\begin{array}{rlr}
d \mathrm{WTB}= & X^{\prime}(\hat{X}+\hat{E})-M^{\prime}(\hat{M}+P \hat{E}) \\
= & \left(X^{\prime}\left[\eta_{x}\right] D-M^{\prime}\right) Z\left[\frac{(1-\tau) Y}{U}\right] \hat{Y} \quad \text { (volume effect of domestic demand) } \\
& +\left(X^{\prime}\left[\epsilon_{x}\right] C-\left(X^{\prime}\left[\eta_{x}\right] D-M^{\prime}\right) J\right) \hat{E} & \text { (volume effect of relative price) } \\
& +\left(X^{\prime}-M^{\prime} P\right) \hat{E} & \text { (price effect of relative price) }
\end{array}
$$

where $U=X+(1-\tau) A, Z=\left(\left[1-\frac{(1-\tau) M}{U}\right]-\left[\frac{\tau X}{U}\right]\left[\eta_{x}\right] D\right)^{-1}$ and $J=Z\left(\left[\epsilon_{m}\right] P-\left[\frac{\tau X}{U}\right]\left[\epsilon_{x}\right] C\right)$.

Equation (14) is verified for every change in domestic output if

$$
X^{\prime}\left[\eta_{x}\right] D=M^{\prime}
$$

Equation (15) expresses conditions on demand elasticities of exports. If all elasticities equal to one, the conditions are satisfied (the definition of world demand implies $X^{\prime} D=M^{\prime}$ ). If some zones have elasticities larger than one (an increase of 1 percent in world trade raises the zone's exports by more than 1 percent), this needs to be offset by elasticities smaller than one for some other zones. One would expect that the export elasticity of one country can compensate for the elasticities of all others such that the sum of export shares remains constant. As of matter of fact, the opposite is true: generally, $N-1$ of the above relationships are independent from each other, so that the choice of the elasticity of one country decides the elasticities of all others.

Equation (14) is verified for every change in exchange rate if

$$
X^{\prime}\left[\epsilon_{x}\right] C=0
$$

Equation (16) expresses conditions on price elasticities of exports. It implies that price elasticities of exports are no longer independent: by choosing a price elasticity for one country, the price-elasticities of all other countries are determined.

\section{THE EQUILIBRIUM EXCHANGE RATE MODEL}

In its seminal work, Nurkse (1945) defined the equilibrium exchange rate (EER) of an economy as the exchange rate which allows to achieve simultaneously internal (full employment) and external (no current-account deficit or surplus) balance. Although the definitions of internal and external balances have evolved since then, they are still in this vein. Williamson (1985) defines the fundamental equilibrium exchange rate (FEER) as the exchange rate "generating for every country a current-account surplus or deficit equal to the underlying capital flow over the 
cycle, given that the country is pursing internal balance as best it can and not restricting trade for balance of payments reasons" (chap. 2, p. 14).

Several approaches have been developed to define "the underlying capital flow" or, synonymously, "the current-account target". It is usually associated with a stabilizing debt to GDP ratio (Joly et al., 1996, 1999). Other approaches use a more general criterion of sustainability (Williamson, 1991, 1994, 2000; Wren-Lewis \& Driver, 1998) related to the internal determinants of the saving-investment balance, such as the stage of development, demographic factors, the tax system, etc. Much of the criticism addressed to the FEER approach is related to these various concepts of the external balance which define the current-account target in a rather $a d$ hoc way. The work presented here does not overcome this deficiency, but this flexibility regarding the definition of the target allows adapting the approach to very different problems. This paper uses the targets calculated by Williamson \& Mahar (1998).

The implementation of the methodology requires a trade model that links current accounts, GDPs and real exchange rates of the different countries. Most of the FEER literature assumes that the current account can be reasonably approximated with traditional exports and imports equations. Obstfeld \& Rogoff (2001) was the first paper of a series where the two authors evaluate FEERs using a trade model that derives from a utility-based demand for domestic and foreign goods. Whatever the trade model in use, the framework can be summarized as

$$
\begin{array}{cl}
Y=\bar{Y} & \text { Internal balance } \\
C A(Y, F E E R)=C A^{\text {target }} & \text { External balance }
\end{array}
$$

In this paper, we stick to the traditional trade model, as presented in Section 2. Furthermore, the current-account variations are identified with those of the trade balance. ${ }^{7}$ Given current accounts registered in statistics, trade volumes have first to be adjusted for output gaps (internal balance) and past exchange-rate variations (the J-curve). Those adjusted current accounts are labelled "underlying current accounts". Then, any current-account variation is obtained through a variation of exchange rates, which writes in our trade model: ${ }^{8}$

$$
d \mathrm{tb}=\left\{\left[\mu_{x}\right]\left[\epsilon_{x}\right] C+\left(\left[\mu_{m}\right]-\left[\mu_{x}\right]\left[\eta_{x}\right] D\right) J-\left[\mu_{m}\right](P-[1])\right\} \hat{E}
$$

Where $d \mathrm{tb}=\left(d \mathrm{tb}_{1}, \ldots, d \mathrm{tb}_{N}\right)^{\prime}$ represents trade-balance variation of the different countries (percentage of GDP). In equilibrium, the variation in the trade balances matches the gap between current-account targets $\left(c a^{*}=\left(c a_{1}^{*}, \ldots, c a_{N}^{*}\right)^{\prime}\right)$ and underlying current accounts $(\overline{c a}=$ $\left.\left(\overline{c a}_{1}, \ldots, \overline{c a}_{N}\right)^{\prime}\right)$, both in percentage of GDP. The right-hand side of the equation can be rewrited

\footnotetext{
${ }^{7}$ Among others, the variations of the balance of the incomes of interest due to the effects of valuation, as in Gourinchas \& Rey (2007), are ignored.

${ }^{8}$ the derivation is similar to the derivation of Equation (14), notations are identical.
} 
in a more compact way, leading to the following equilibrium equation:

$$
c a^{*}-\overline{c a}=\Gamma^{-1} K \hat{E}
$$

The relation between the exchange-rate variation and trade-balance adjustments can be decomposed into two blocks:

- $\Gamma=\operatorname{diag}\left(\beta_{i}\right)$ is a diagonal matrix whose coefficients are related to Marshall-Lerner condition: $\beta_{i}>0$ implies that a depreciation of the exchange rate leads to an improvement of the current account (see Table 1).

- $K$ is a matrix such that the sum of its columns is equal to zero and its diagonal only contains the number -1 . The raw $i$ column $j$ coefficient of matrix $K$ can be interpreted as the share of the currency of the zone $j$ in the "true" real effective exchange rate of country $i$, the one which measures the effect of the variations of the exchange rate on the trade balance and not only on the volume of the exports. Some of them may be negative when (i) goods of country $j$ are little in competition with those of country $i$ on third markets and (ii) the share of $j$ in $i$ 's imports is large. In this case, an appreciation of the currency of country $j$ will weakly increase the exports of the country $i$ but will weigh on its imports, with a negative effect on the current account.

\section{THE OVER IDENTIFICATION PROBLEM WITH N COUNTRIES}

In Equation (17), there are only $N-1$ independent bilateral exchange rates (zero is an eigenvalue with multiplicity 1 of matrix $K$ ) but $N$ variations of the trade balance, so all the current-account targets cannot be reached simultaneously. The problem has for origin the independent evaluation of the target of each zone (the left hand side of the equation), so the global consistency of targets (the fact that the net saving of the world is zero) is not guaranteed. Even if ex ante, they are chosen such that they sum to zero at the world level for actual exchange rate, this is no more the case ex post, for equilibrium exchange rate. At the same time, the variation of trade balances compatible with exchange-rate variations (the right hand side of the equation) is a sub-space of dimension $N-1$ (Faruqee \& Isard, 1998) which is coincident with the sub-space of world-consistent current accounts (see Section 2).

The variable which balances saving and investment at the world level, when the activity is at potential, is the world interest rate. In FEER models, it plays the role of the missing endogenous variable. The natural solution of the overidentification problem would be to introduce the interest rate as a determinant of current-account targets. However, this is not the solution used in the literature to circumvent the overidentification problem. ${ }^{9}$ Here we discuss how this problem

\footnotetext{
${ }^{9}$ This literature has always been directed towards practical issues, i.e. the detection of manifest misalignment of exchange rates. As far as estimated bilateral exchange rates drive each country close to its external equilibrium, it is superfluous to complicate the model with additional elements (the link between the world interest rate and
} 
has been tackled. We can classify the methodologies used in two types: those which ignore the balance of one zone, and those which take into account all the zones to define the equilibrium, but do not reach it completely. This section presents the different methods and proposes two original ones that belong to the second option, while trying to improve the existing approaches. As an illustrative example, we consider a model in three zones numbered 1,2 and 3 . We refer to Section 5.2.2 for a discussion of the relevance of each methodology by implementing them for a 20 countries model.

\subsection{Ignoring one zone's equilibrium}

One way of addressing the overidentification problem is to drop one current-account adjustement. In the literature, the ignored zone is usually the RoW (Alberola et al., 2000; BénassyQuéré et al., 2006) which is denoted here by the number 3. In this method, the relation between the real effective exchange rate of the RoW and the level of its current account is not used to determine the bilateral equilibrium exchange rates. Formally, the exchange rates are determined from the equations of misalignment of the first two zones:

$$
\hat{c a_{1}}=c a_{1}^{*}-\overline{c a}_{1}=\frac{1}{\beta_{1}} K_{1} \hat{E} \text { and } \quad \hat{c a} a_{2}=c a_{2}^{*}-\overline{c a}_{2}=\frac{1}{\beta_{2}} K_{2} \hat{E}
$$

Here, we choose zone 1 as the reference currency $\left(\hat{e}_{1}=0\right)$. This choice has no influence on the equilibrium and is not related to the ignored zone. Both equations rewrite: ${ }^{10}$

$$
K_{(-1)}^{(-3)}\left(\begin{array}{c}
\hat{e}_{2} \\
\hat{e}_{3}
\end{array}\right)=\left(\begin{array}{c}
\beta_{1} \hat{c a} \\
\beta_{2} \hat{c} a_{2}
\end{array}\right)
$$

The two unknowns are the misalignments of the bilateral exchange rates of zones 2 and 3 with regard to the currency of zone 1. The relation above being invertible, the equilibrium bilateral exchange rates are defined in a unique way: $\hat{E}_{\mathrm{eq}}=\left(0, \hat{e}_{2}, \hat{e}_{3}\right)^{\prime}$. Only the currentaccount imbalances of zones 1 and 2 intervene in the calculation of the equilibrium exchange rates; the current-account imbalance of zone 3 is ignored. This method knows two refinements that interpret the equilibrium so defined.

\subsubsection{Absence of target for the Rest of the World}

If trade of the RoW is modelled, the method allows calculating, in an endogenous way, the current-account target of the RoW. It is then defined as the current account consistent with the effective misalignment of the RoW's currency:

current-account targets). However, if the gap is too large, the level of the world interest rate starts to be a practical issue.

${ }^{10}$ We denote $K_{(-j)}^{(-i)}$ the matrix $\mathrm{K}$ where line $i$ and column $j$ are canceled. Line $i$ is canceled because the equilibrium of country $i$ is ignored and column $j$ is canceled because the currency of country $j$ is taken as the numeraire. 


$$
c a_{3}^{*}=\overline{c a}_{3}+\frac{1}{\beta_{3}} K_{3} \hat{E}_{\mathrm{eq}}
$$

The imbalance of the RoW is simply the opposite of the imbalance of the other zones: the model "settles" on the RoW (Barrell \& Wren-Lewis, 1989; Borowski et al., 1998; Borowski \& Couharde, 1999, 2000; Coudert \& Couharde, 2005). In fact, the information brought by the actual situation of the RoW (trade structure, the underlying current account, fundamentals of the economy) is not exploited to estimate the equilibrium exchange rates. This may lead to inaccurate exchange rates if the RoW is small so that its implicit target may be unreasonable. Barrell \& Wren-Lewis (1989) specifically study this problem and find that estimated exchange rates are consistent so the RoW is closed to equilibrium.

\subsubsection{Absence of specification for the Rest of the World's trade equations}

From the equilibrium exchange rates calculated above, some authors (Jeong \& Mazier, 2003) ensure the locking up in value and in volume of world trade by adjusting the volume of imports and exports of the RoW. More exactly, imports and exports in volume (i.e. at constant price) of the RoW are defined from the two following equations:

$$
\sum_{i} P_{m i} M_{i}=\sum_{i} P_{x i} X_{i} \quad \text { and } \quad \sum_{i} M_{i}=\sum_{i} X_{i}
$$

They do not thus derive from a specification of the volume of the RoW's trade according to its effective exchange rate. As the real effective exchange rate of the RoW and the variation of the volume of its imports and its exports are independently determined, the implicit relation between the real effective exchange rate of the RoW and the volume of imports and exports (the implicit price-elasticities) risks being quite unlikely, especially when the RoW is small.

\subsection{Sharing out between all zones the inconsistency of the targets}

\subsubsection{The Cline's new symmetric matrix inversion method}

Considering the limits of the methods which ignore one zone's equilibrium, Cline (2008) and Cline \& Williamson $(2008,2009)$ propose an alternative method. In a nutshell, they estimate as many bilateral equilibrium exchange rates as zones in the model, each one ignoring the equilibrium of one zone. Then, they consider two different definitions of bilateral equilibrium exchange rates: the simple average of these estimates (All Countries Included, ACI) or the average when excluding the bilateral misalignment of the ignored country (Other Countries Included, OCI). Let $\hat{E}^{k}=\left(0, \hat{e}_{2}^{k}, \hat{e}_{3}^{k}\right)^{\prime}$ the vector of equilibrium exchange rates when ignoring zone $k$ (the numeraire currency has to be the same for all the estimations). The two concepts write: 


$$
\hat{E}^{\mathrm{ACI}}=\left(0, \frac{\hat{e}_{2}^{1}+\hat{e}_{2}^{2}+\hat{e}_{2}^{3}}{3}, \frac{\hat{e}_{3}^{1}+\hat{e}_{3}^{2}+\hat{e}_{3}^{3}}{3}\right) \text { and } \hat{E}^{\mathrm{OCI}}=\left(0, \frac{\hat{e}_{2}^{1}+\hat{e}_{2}^{3}}{2}, \frac{\hat{e}_{3}^{1}+\hat{e}_{3}^{2}}{2}\right)
$$

Cline claims that the OCI method is better than the ACI one: it provides estimated exchange rates that drive each economy closer to its external equilibrium. However, even in the OCI case, some countries may experience bad results.

\subsubsection{The readjustment of the misalignments}

Faruqee \& Isard (1998) proposes a method allowing to treat symmetrically all the zones of the model. They start from a variation of Equation (17):

$$
\Gamma \hat{c a}=K \hat{E}
$$

The left-hand side represents the real effective realignments that close the gap between underlying and target current accounts, called ex ante realignments. Consistent realignments (righthand side) form a sub-space of dimension $N-1$ of the space of the effective misalignments (which is of dimension $N$ ). From then on, it is enough to project ex ante realignments on the space of the consistent realignments. The authors choose a specific projection by adding to the ex ante realignment of every zone the same value which will be adjusted so that ex post realignments are effectively in the space of the consistent realignments:

$$
\Gamma \hat{c a}+z=K \hat{E}
$$

By taking as numeraire the currency of the zone 1 , this equation rewrites:

$$
\left(\begin{array}{c}
\hat{e}_{2} \\
\hat{e}_{3} \\
z
\end{array}\right)=\left(\begin{array}{lll}
k_{1,2} & k_{1,3} & -1 \\
k_{2,2} & k_{2,3} & -1 \\
k_{3,2} & k_{3,3} & -1
\end{array}\right)^{-1}\left(\begin{array}{c}
\beta_{1} \hat{c} a_{1} \\
\beta_{2} \hat{c} a_{2} \\
\beta_{3} \hat{c a} a_{3}
\end{array}\right)
$$

This method presents the advantage of taking into account all the zones but ends in little satisfactory results as far as the reached ex post current accounts deviate, sometimes considerably, from ex ante targets (Carton et al., 2007; Hervé, 2004). This method of adjustment corresponds to no economic nor mathematical criterion. In fact, instead of trying to approach ex ante realignments, it seems more sensible to try to approach directly the current-account targets.

\subsubsection{Minimize target gaps}

We propose here an original method to circumvent the overidentification problem. The purpose of the method is to find ex post current accounts that are (i) consistent with a variation of bilateral 
exchange rates and (ii) as close as possible to current-account targets. So we define a distance between the ex post current accounts $\left(\mathrm{ca}_{i}\right)$ and current-account targets $\left(c a_{i}^{*}\right)$ :

$$
d^{2}=\sum_{i} \alpha_{i}\left(\mathrm{ca}_{i}-c a_{i}^{*}\right)^{2}=\left(\mathrm{ca}-c a^{*}\right)^{\prime}[\alpha]\left(\mathrm{ca}-c a^{*}\right)
$$

The weight $\alpha_{i}$ given to each zone has no a priori value. We propose to link it to the GDP of the zone expressed in PPP: $\alpha_{i}=\sqrt{Y_{i}}$. The square root was chosen so as to allow small countries to be weighted in the distance measure, hence to lie not too far from their targets. The program is then written:

$$
\min _{\mathrm{ca}, \hat{E}}\left(\mathrm{ca}-c a^{*}\right)^{\prime}[\alpha]\left(\mathrm{ca}-c a^{*}\right) \text { under the constraint } \Gamma(\mathrm{ca}-\overline{c a})=K \hat{E}
$$

This program defines a unique vector of bilateral equilibrium exchange rates.

\subsubsection{Equalize target gaps}

Minimizing target gaps is a very general method, as each other method is a special case. But it may appear ad hoc, as there is no natural way to choose the distance. We then propose a special case that consists in equalizing target gaps between countries. ${ }^{11}$ This leads to the following equation:

$$
\hat{c a}+z=\Gamma^{-1} K \hat{E}
$$

This method is closed to the one proposed by Faruqee and Isard but instead of assuming a common correction for effective exchange rates, we assume here a common correction for target gaps. Contrary to existing methods that lack economic meaning, this one relies on the role of the world interest rate in the world equilibrium: if the sensitivity of current-account target to the world interest rate is similar for all countries, we then obtain precisely this method. By taking as numeraire the currency of the zone 1 , this equation rewrites

$$
\left(\begin{array}{c}
\hat{e}_{2} \\
\hat{e}_{3} \\
z
\end{array}\right)=\left(\begin{array}{ccc}
k_{1,2} / \beta_{1} & k_{1,3} / \beta_{1} & -1 \\
k_{2,2} / \beta_{2} & k_{2,3} / \beta_{2} & -1 \\
k_{3,2} / \beta_{3} & k_{3,3} / \beta_{3} & -1
\end{array}\right)^{-1}\left(\begin{array}{c}
\hat{c} \hat{a}_{1} \\
\hat{c} a_{2} \\
\hat{c} a_{3}
\end{array}\right)
$$

This program defines a unique vector of bilateral equilibrium exchange rates.

\footnotetext{
${ }^{11}$ This corresponds to the minimization of the distance given by $\max _{i}\left(\mathrm{ca}_{i}-c a_{i}^{*}\right)$.
} 


\section{FEER FOR 19 INDUSTRIALISED AND EMERGING COUNTRIES}

This section implements the various methodologies presented in section 4 for 19 countries (the United States, the euro area, Canada, United Kingdom, Japan, Australia, New Zealand, Mexico, Brazil, India, Indonesia, South Korea, Hong Kong, Singapore, Taiwan, Malaysia, Philippine, Thailand and China) and the rest of the world for the 2000-2008 period. ${ }^{12}$ It also discusses the relevance of these various methodologies. The original one we propose here was implemented in Carton et al. (2006). The present paper details the methodology and updates the results.

\subsection{Trade parameters and other structural data}

\subsubsection{Constraints imposed on trade parameters}

The FEER is very sensitive to trade price elasticities. As shown by various studies (Bayoumi, 1999; Hervé, 2001; Murata et al., 2000; Hooper et al., 1998; Marquez, 1990), trade elasticities vary considerably according to the econometric method and the scope of trade (manufactured goods, goods, goods and services), etc.

In this paper, to ensure the locking up of the model, some trade elasticities are constrained (see Section 2). The foreign demand elasticity of exports is fixed to unity because the foreign demand is a balanced sum of the imports of others countries. The domestic demand elasticity of imports is also unity. The price elasticities of imports are not constrained. We take the elasticities of the Multimod model of the IMF which are estimated for two groups of countries: industrial nations on the one hand and emerging countries on the other hand. Price elasticities of exports are constrained by the condition of locking up in volume, which leaves only a single degree of freedom. The choice was made to calibrate the price elasticity of exports of developed countries based on Multimod (see Table 1).

\subsubsection{Openness and current-account sensitiveness to exchange-rates variations}

Industrial nations are relatively little open altogether, presenting an average export or import to GDP ratio lower than $20 \%$ (with the exception of Canada). Because of their size, it is also the case of Brazil and India. On the contrary, Singapore, Hong-Kong and Malaysia are extremely open with ratios exceeding to $100 \%$, which suggests that a weaker correction of their exchange rate is necessary to return to equilibrium, other things equal. China, Korea and Indonesia have openness close to industrial countries, slightly superior however, of the order of 25 to $30 \%$. The other countries have intermediate levels of openness.

The current-account sensitivity to exchange rates is summarized by the term $1 / \beta$, which represents the percentage of depreciation of the real exchange rate to improve the current account of a country by 1 percentage point of GDP. Countries with a weak $1 / \beta$ have a strong sensitivity of

\footnotetext{
${ }^{12}$ Countries have been chosen such that largest developed (the USA, the euro area and Japan) and developing economies (China, India and Brazil) and the bulk of their trade partners are taken into account.
} 
Table 1 - Current-account targets and structural parameters (in 2008)

\begin{tabular}{lcccccc}
\hline & $X$ & $M$ & $\begin{array}{c}\text { Export price } \\
\text { elasticity }\left(\epsilon_{x}\right) \text { elasticity }\left(\epsilon_{m}\right)\end{array}$ & $1 / \beta$ & ca $^{*}$ \\
\hline USA & 0.13 & 0.18 & 0.70 & 1.81 & 10.83 & -2.0 \\
EUR & 0.21 & 0.20 & 0.56 & 1.51 & 7.25 & 1.2 \\
CAN & 0.35 & 0.33 & 0.73 & 1.22 & 4.18 & -1.9 \\
GBR & 0.29 & 0.32 & 0.84 & 1.36 & 4.61 & -0.2 \\
JPN & 0.18 & 0.18 & 0.80 & 1.58 & 7.58 & 1.9 \\
AUS & 0.24 & 0.24 & 0.84 & 1.45 & 5.86 & -3.7 \\
NZL & 0.31 & 0.33 & 0.88 & 0.98 & 7.64 & -3.7 \\
MEX & 0.28 & 0.31 & 0.81 & 1.02 & 8.51 & -3.0 \\
BRA & 0.15 & 0.14 & 0.91 & 1.26 & 12.68 & -3.0 \\
IDN & 0.30 & 0.28 & 0.86 & 0.98 & 7.31 & -4.1 \\
IND & 0.22 & 0.28 & 0.89 & 1.15 & 11.16 & -2.1 \\
KOR & 0.54 & 0.55 & 0.85 & 0.74 & 4.96 & -0.2 \\
HKG & 2.12 & 2.01 & 0.74 & 0.27 & 1.76 & 3.7 \\
SGP & 2.34 & 2.15 & 0.77 & 0.24 & 1.45 & 4.2 \\
TWN & 0.74 & 0.69 & 0.86 & 0.60 & 3.60 & 3.1 \\
MYS & 1.01 & 0.78 & 0.85 & 0.46 & 2.32 & -2.8 \\
PHL & 0.35 & 0.41 & 0.88 & 0.96 & 7.88 & -4.1 \\
THA & 0.77 & 0.75 & 0.87 & 0.59 & 3.63 & -4.2 \\
CHN & 0.38 & 0.30 & 0.77 & 0.85 & 5.31 & -1.0 \\
ROW & 0.29 & 0.27 & 0.59 & 0.98 & 7.31 & 2.0 \\
\hline
\end{tabular}

Sources : Opening rates are derived from trade of goods and services Datastream; Price elasticities in the import equation are derived from Multimod (in this table, we report structural import-price elasticities consistent with the extended form, Equation (11), import-price elasticities of the corresponding reduced form, Equation (8), are set, as in Multimod, to 0.92 for industrialized countries and 0.69 for emerging countries); Price elasticities in the export equation are calculated by authors in order to verify the global consistency of the model. 
their current accounts to exchange-rate variations. So, for these countries, a small correction of the exchange rate is necessary to move the current account to its target. It is the case of most of the Asian countries held in the sample. On the other hand, the United States, India and Brazil need a large variation of their exchange rate to meet the equilibrium.

\subsubsection{The underlying current account}

To evaluate underlying current accounts, we estimate output gaps and the dynamics of adjustment of trade volumes to the exchange-rates variations. Output gaps are derived from series of annual real GDP from 1990 to 2014 (IMF WEO, Spring 2009, forecast for 2009-2014 period) in $\log$. The cycle is estimated with a Hoddrick-Prescott filter with smoothing parameter 400. For the J-curve correction, we rely on the estimation by Bayoumi (1999) and assume that, at year $t$, the current account completely registered the effects of exchange-rates variations on imports prices (exports prices are not affected because there is no margin behavior). On the other hand, trade volumes fit more gradually: at year $t$, trade volumes are assume to have completely absorbed exchange-rate variations of period $t-2$, while only accounting for $85 \%$ and $60 \%$ of $t-1$ and $t$ exchange-rate variations respectively. Comparing targets and underlying current accounts provides a first idea on exchange-rate misalignments. The gap is particularly marked for the Asian countries (See Figure A.1).

\subsection{Equilibrium exchange rates}

\subsubsection{Results}

Real effective misalignments obtained with the ETG methodology are reported in Appendix Table A.1. The values retained for the current-account targets (i.e. external balances) are those proposed by Williamson \& Mahar (1998) but amended in the case of China. Indeed, in the initial article of Williamson and Mahar, China, which is a catching up country, is supposed to be able to record a deficit of $2.8 \%$ of GDP. However, the Chinese target being considered to be excessive by many authors, including Williamson himself, we modified it and retained a current-account deficit of $1 \%$ of GDP.

The 2008-2009 economic crisis has strongly modified the assessment on output gaps in many areas. In the U.S., the underlying current account improved from 2002 to 2008 whereas the observed current account registered the well-known huge deterioration. Thus the dollar appears less overvalued than in estimations based on pre-crisis output gaps assessments. The euro and the US dollar were overvalued by approximately $15-20 \%$ in 2006. In 2007-2008 the US dollar, with an overvaluation of $10 \%$, would be close to its equilibrium regarding to the uncertainties related to the calculations of equilibrium exchange rates. On the opposite, the overvaluation of the euro would have more than doubled. The equilibrium bilateral parity is estimated around 1.30 USD. In 2006-2007, the British pound and the Australian and Canadian dollars, which were substantially overvalued (25-30\% in real effective terms), have converged to their equilibrium in 2008. 
The real effective undervaluation of the Chinese currency seems to have reached a peak in 2007 $(46 \%)$ and remains massive in $2008(40 \%)$. With respect to the US dollar this undervaluation would be even more marked (50\%). After a decade of undervaluation, Japanese yen seems to have converged to equilibrium in recent years. The other Asian currencies appear significantly undervalued with respect to the US dollar, in particular in 2008.

Given the sensitiveness of equilibrium exchange rate calculations to the assumptions retained on current-account targets, we contemplate running an alternative scenario where China's target is a surplus of $3 \%$ of GDP (instead of a deficit of $1 \%$ ). This new assumption implies a higher Chinese saving rate and more foreign capital outflows than in the previous scenario. We consider the counterpart as a smaller US saving rate and set US current-account target to $-3 \%$ of GDP (instead of a deficit of $2 \%$ ). In this scenario, the dollar appears at its equilibrium value in real effective terms in 2008. The undervaluation of the Chinese currency is lowered by $20 \%$ and equals to $18 \%$ in 2008 . The overvaluation of the European currency with respect to the US dollar would be double (21\%) and the equilibrium parity would be 1.20 USD instead of 1.30 USD with the previous set of current-account targets.

\subsubsection{Relevance of the methodologies}

The method 'ignoring one zone' should lead to appropriate equilibrium exchange rates if the current account reached by the ignoring zone is on line with its external equilibrium. Nevertheless, it is not ensured. Table 2 figures out, for each estimation of equilibrium exchange rates through the method 'ignoring one zone', the target gap of the country whose equilibrium is ignored (others countries reach exactly their target, see section 4.1). Ignoring the RoW leads to a large target gap, around 2\% of RoW's GDP. Smallest target gaps (ratio to GDP) appear when ignoring largest economies: the US (1\% of GDP) or the euro area (1.5\% of GDP). But this approach is in contradiction with the goal of the FEER method: estimating exchange rates consistent with global rebalancing. Ignoring another country leads to absurd results (a gap of $4 \%$ for Japan, $8 \%$ for China etc.).

Table 2 - Gap to current-account targets when ignoring one zone (\% of GDP)

\begin{tabular}{cccccccccc}
\hline USA & EUR & CAN & GBR & JPN & AUS & NZL & MEX & BRA & IDN \\
-0.9 & -1.5 & -11.1 & -6.6 & -4.2 & -19.7 & -136.9 & -12 & -12.7 & -48.8 \\
\hline IND & KOR & HKG & SGP & TWN & MYS & PHL & THA & CHN & ROW \\
-10.1 & -19.8 & -112.7 & -148.1 & -58.6 & -192 & -78 & -79.8 & -7.6 & -1.9 \\
\hline
\end{tabular}

Table A.3 in the Appendix compares the difference between achieved (ex post) and targeted current accounts for methods that share out the target's inconsistency. Our results comfort Cline's suggestion in favor of the OCI method versus the ACI's one which produces large gaps between current-account targets and ex post current accounts, particularly for small countries. But, even in the OCI's method, some countries are still far from their target (more than 5\% 
of GDP for Singapore). Faruqee and Isard's 'readjustment of misalignments' method avoids so large gaps, even so Singapore still registers a $1.5 \%$ gap. The overdetermination problem necessarily implies a trade-off between current-account gaps of countries. Methods used in the literature generally favour large countries to the detriment of small ones without this result being deliberate. From this point of view, our method is at the same time more explicit on the goal to reach (minimizing target gaps for all countries) and more efficient (the largest gap is less than $0.5 \%$ of GDP). Equalizing target gaps allows limiting the target gap to $0.3 \%$ of GDP for each zone.

\section{Conclusion}

This paper proposes a methodology that aims to estimate world-consistent fundamental equilibrium exchange rates (FEER). We first derive conditions on trade-elasticities of the underlying trade model such that the evolutions of the trade balance of the different countries are compatible with world-trade balance. We then suggest a method to circumvent the overidentification problem that arises in multi-country FEER estimations. Based on the estimation of consistent equilibrium exchange rates for 19 countries and the rest of the world, this method appears more efficient than other methods proposed in the literature. It can also be implementable in more general framework, including the separate estimation of oil-related trade balance, margin behavior of exporters, etc. 


\section{BIBLIOGRAPHY}

Alberola, E., Cervero, S., Lopez, H., \& Ubide, A. (2000). Global Equilibrium Exchange Rates: Euro, Dollar," Ins,"" Outs," and Other Major Currencies in a Panel Cointegration Framework. Technical report.

Barrell, R. \& Wren-Lewis, S. (1989). Fundamental Equilibrium Exchange Rates for the G7. CEPR Discussion Papers 323, C.E.P.R. Discussion Papers.

Bayoumi, T. (1999). Estimating Trade Equations from Aggregate Bilateral Data. IMF Working Papers 99/74, International Monetary Fund.

Bénassy-Quéré, A., Lahrèche-Révil, A., \& Mignon, V. (2006). World Consistent Equilibrium Exchange Rates. CEPII working paper 2006-20, CEPII.

Borowski, D. \& Couharde, C. (1999). Quelle parite d'equilibre pour l'euro ? Economie Internationale, (1Q), 21-44.

Borowski, D. \& Couharde, C. (2000). Euro, dollar, yen : pour une approche multilatéral des taux de change d'équilibre. Revue Économique.

Borowski, D., Couharde, C., \& Thibault, F. (1998). Les taux de change d'équilibre fondamentaux : de l'approche théorique à l'évaluation empirique. Revue française d'économie, 13.

Carton, B., Herve, K., \& Terfous, N. (2006). Interventions de change en asie et taux de change d'équilibre du dollar. Economie Internationale, (2Q), 57-84.

Carton, B., Hervé, K., \& Terfous, N. (2007). Méthode d'estimation des taux de change d'équilibre fondamentaux dans un modèle de commerce bouclé. Documents de travail de la DGTPE 2007/12, Direction Générale du Trésor et de la Politique Économique.

Cline, W. R. (2008). Estimating Consistent Fundamental Equilibrium Exchange Rates. Working Paper 08-6, Peterson Institute for International Economics.

Cline, W. R. \& Williamson, J. (2008). New Estimates of FEERs. Policy Brief 08-7, Peterson Institute for International Economics.

Cline, W. R. \& Williamson, J. (2009). 2009 Estimates of Fundamental Equilibrium Exchange Rates. Policy Brief 09-7, Peterson Institute for International Economics.

Coudert, V. \& Couharde, C. (2005). Real Equilibrium Exchange Rate in China. Working Papers 2005-01, CEPII research center.

Faruqee, H. \& Isard, P. (1998). Exchange Rate Assessment: Extension of the Macroeconomic Balance Approach. IMF Occasional Papers 167, International Monetary Fund.

Gourinchas, P.-O. \& Rey, H. (2007). International financial adjustment. Journal of Political Economy, 115, 665-703.

Hervé, K. (2001). Estimations des élasticités du commerce extérieur sur l'ensemble des biens et services pour un panel de 17 pays. Économie et Prévision, 147.

Hervé, K. (2004). Une nouvelle approche du taux de change d'équilibre à partir des équations 
du commerce extérieur: Une application aux grands pays industrialisés et aux nouveaux états membres de l'Union européenne. PhD thesis, Université Paris Nord.

Hooper, P., Johnson, K., \& Marquez, J. (1998). Trade elasticities for G-7 countries. International Finance Discussion Papers 609, Board of Governors of the Federal Reserve System (U.S.).

Jeong, S.-E. \& Mazier, J. (2003). Exchange Rate Regimes and Equilibrium Exchange Rates in East Asia. Revue Économique, 54.

Joly, H., Prigent, C., \& Sobczak, N. (1996). Le taux de change réel d'équilibre : une introduction. Économie et Prévision, 123-124.

Joly, H., Prigent, C., \& Sobczak, N. (1999). Une estimation du taux de change réel d'équilibre pour l'économie française. Économie Internationale, 77.

Marquez, J. (1990). Bilateral trade elasticities. The Review of Economics and Statistics, 72(1), 70-77.

Murata, K., Turner, D., Rae, D., \& Fouler, L. L. (2000). Modelling Manufacturing Export Volumes Equations: A System Estimation Approach. OECD Economics Department Working Papers 235, OECD Economics Department.

Nurkse, R. (1945). Conditions of international monetary equilibrium. Readings in the Theory of International Trade. The Blakiston Company.

Obstfeld, M. \& Rogoff, K. (2001). Perspectives on OECD Economic Integration: Implications for US Current Account Adjustment. International Trade 0012004, EconWPA.

Williamson, J. (1985). The Exchange Rate System. Technical report, Institute of International Economics.

Williamson, J. (1991). Feers and the erm. National Institute Economic Review, 137, 45-50.

Williamson, J. (1994). Estimating Equilibrium Exchange Rates. Peterson Institute.

Williamson, J. (2000). Exchange Rate Regimes for Emerging Markets: Reviving the Intermediate Option. Peterson Institute.

Williamson, J. \& Mahar, M. (1998). Real Exchange Rates for the Year 2000, chapter Current Account Targets, (pp. 75-118). In Wren-Lewis \& Driver (1998).

Wren-Lewis, S. \& Driver, R. (1998). Real Exchange Rates for the Year 2000. Peterson Institute. 


\section{APPENDIX}

Figure A.1 - Actual (black line) and underlying (grey line) current accounts (2000-2008)
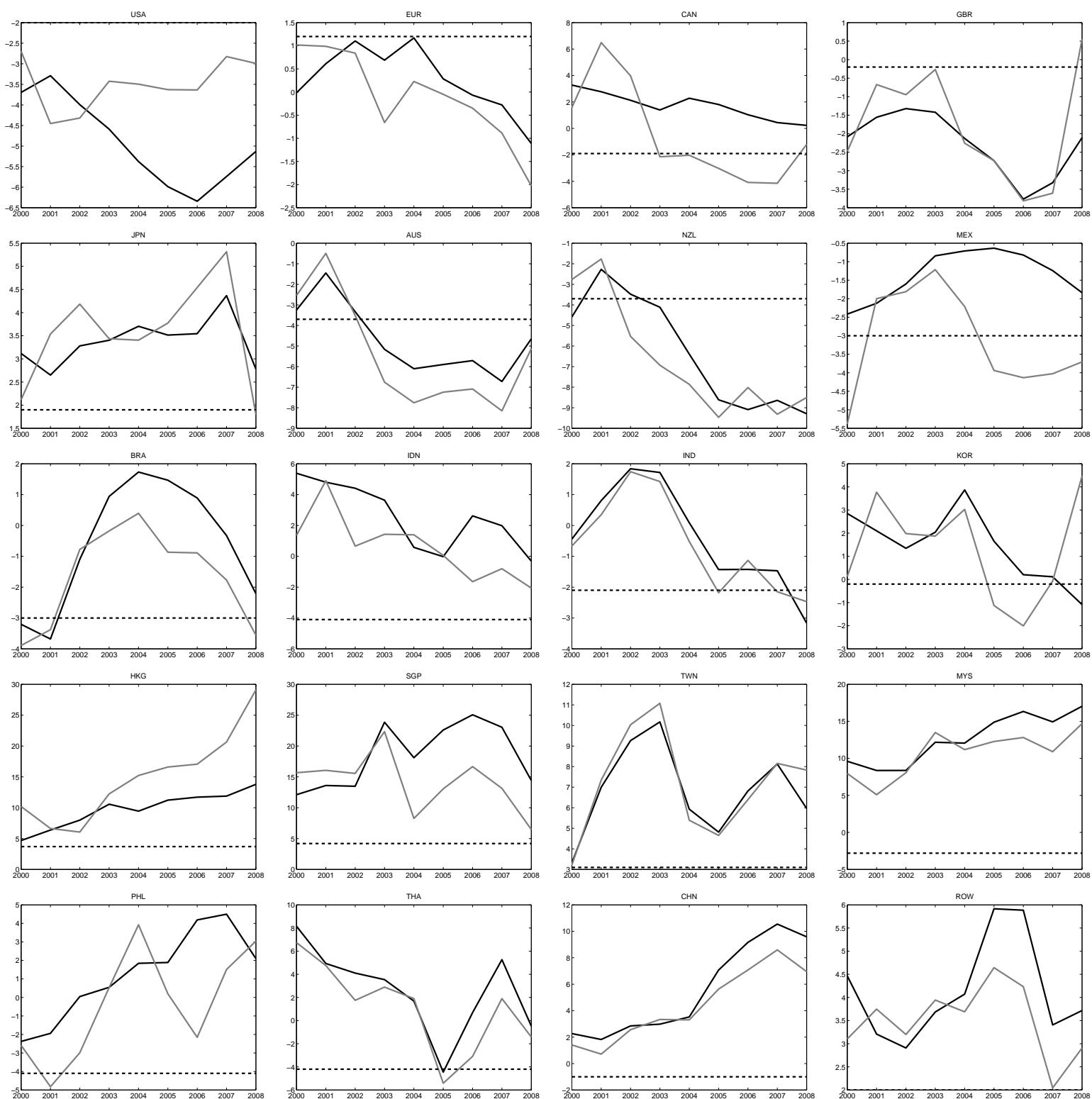
Figure A.2 - Estimated output-gap
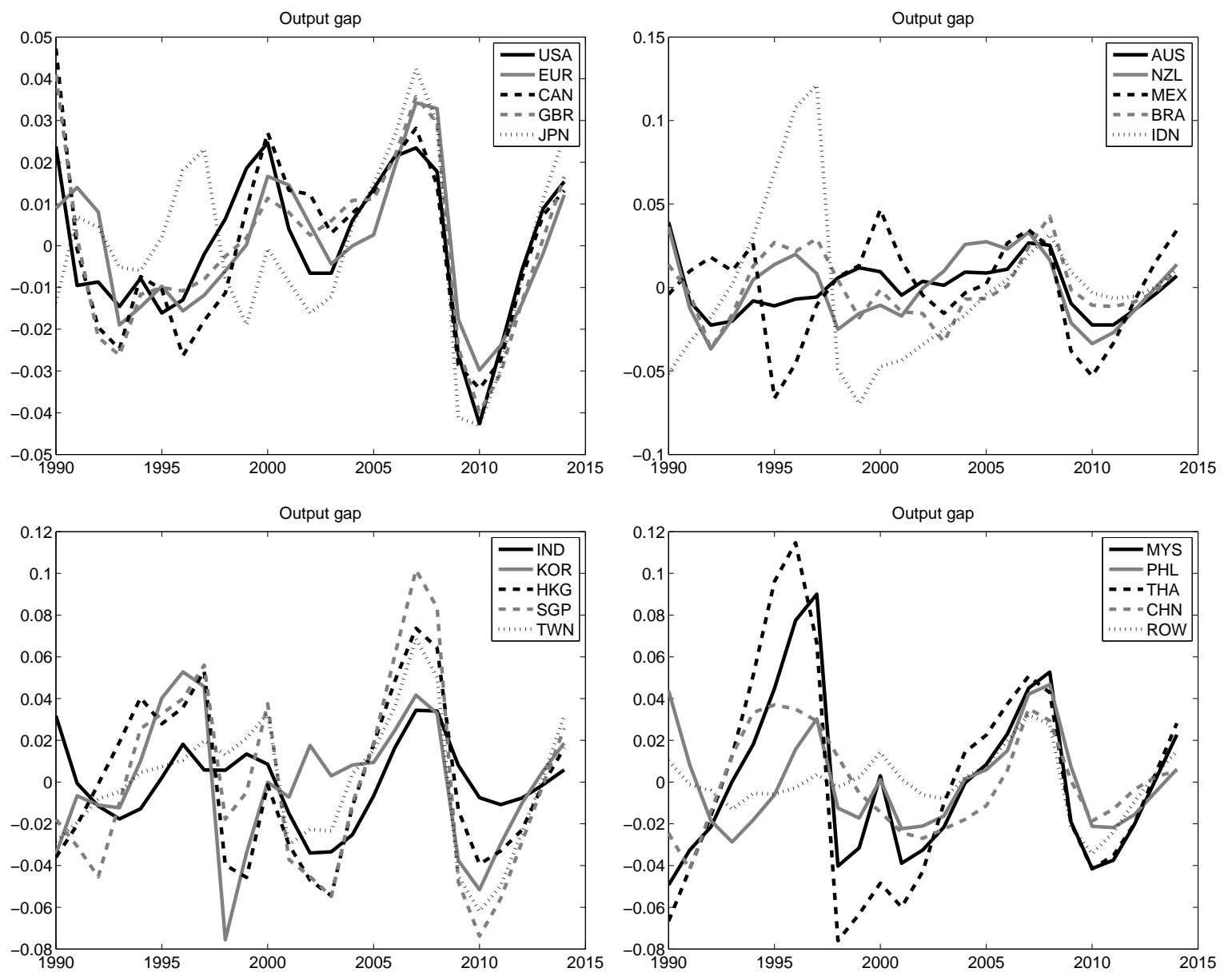
Table A.1 - Real effective misalignments (ETG method)

\begin{tabular}{lcccccccccc} 
& 2000 & 2001 & 2002 & 2003 & 2004 & 2005 & 2006 & 2007 & 2008 & $2008^{*}$ \\
\hline USA & -10.6 & -31.3 & -32.4 & -24.3 & -22.6 & -24.0 & -23.7 & -13.3 & -14.2 & -2.4 \\
EUR & -4.2 & -4.7 & -7.4 & -19.5 & -11.7 & -11.6 & -14.7 & -24.8 & -29.6 & -28.2 \\
CAN & 3.1 & 3.5 & -4.5 & -21.0 & -19.1 & -23.0 & -27.0 & -19.5 & -8.5 & -0.0 \\
GBR & -12.5 & -5.6 & -8.1 & -8.8 & -16.9 & -18.8 & -24.2 & -26.8 & -8.7 & -7.7 \\
JPN & 0.8 & 14.1 & 20.1 & 12.8 & 12.6 & 14.7 & 19.4 & 25.5 & -0.1 & -0.5 \\
AUS & 6.9 & 20.1 & 3.3 & -20.1 & -27.7 & -23.2 & -20.3 & -27.1 & -8.5 & -9.3 \\
NZL & 4.6 & 11.2 & -11.9 & -28.0 & -36.6 & -51.6 & -39.0 & -51.6 & -40.3 & -39.2 \\
MEX & -26.0 & -14.4 & -14.0 & -3.3 & -11.5 & -26.5 & -28.2 & -20.6 & -20.1 & -10.8 \\
BRA & -15.5 & -7.7 & 19.5 & 22.8 & 28.1 & 19.5 & 22.0 & 13.2 & -10.4 & -10.3 \\
IDN & 20.1 & 38.4 & 23.5 & 31.0 & 31.0 & 22.1 & 13.2 & 22.0 & 12.7 & 13.2 \\
IND & 16.9 & 27.5 & 40.9 & 38.0 & 15.2 & -2.6 & 7.9 & -3.0 & -7.0 & -6.1 \\
KOR & -0.6 & 17.0 & 9.3 & 8.6 & 13.7 & -6.8 & -11.3 & 0.9 & 22.6 & 22.0 \\
HKG & 14.1 & -0.5 & 0.7 & 13.5 & 17.5 & 24.3 & 23.0 & 39.7 & 53.8 & 48.2 \\
SGP & 17.2 & 13.3 & 12.6 & 21.1 & 2.9 & 10.1 & 14.0 & 13.1 & 7.3 & 8.2 \\
TWN & -0.6 & 11.8 & 21.2 & 25.1 & 6.0 & 4.4 & 10.2 & 18.6 & 17.3 & 17.2 \\
MYS & 18.4 & 12.9 & 20.1 & 31.5 & 25.3 & 25.4 & 27.3 & 29.5 & 38.5 & 39.4 \\
PHL & 5.6 & -6.0 & 5.1 & 25.0 & 44.4 & 25.0 & 9.7 & 37.2 & 54.8 & 55.2 \\
THA & 30.7 & 24.7 & 15.6 & 19.9 & 17.8 & -7.3 & 0.9 & 18.7 & 7.5 & 8.4 \\
CHN & 14.1 & 10.3 & 22.5 & 22.7 & 21.5 & 31.2 & 35.5 & 45.4 & 38.4 & 18.0 \\
ROW & 3.7 & 6.7 & 2.7 & 5.4 & 5.9 & 11.3 & 8.6 & -8.5 & -5.4 & -3.3 \\
\hline
\end{tabular}

* Targets for USA and China are set to -3 and +3 respectively. $+=$ undervaluation 
Table A.2 - Bilateral equilibrium exchange rates (ETG method)

\begin{tabular}{lcccccccccc} 
& 2000 & 2001 & 2002 & 2003 & 2004 & 2005 & 2006 & 2007 & 2008 & $2008^{*}$ \\
\hline EUR & 0.97 & 1.11 & 1.16 & 1.18 & 1.36 & 1.37 & 1.36 & 1.27 & 1.32 & 1.20 \\
CAN & 1.32 & 1.12 & 1.21 & 1.36 & 1.26 & 1.21 & 1.18 & 1.14 & 1.01 & 1.03 \\
GBR & 0.68 & 0.56 & 0.55 & 0.54 & 0.53 & 0.53 & 0.55 & 0.58 & 0.52 & 0.57 \\
JPN & 96 & 80 & 78 & 82 & 78 & 77 & 78 & 80 & 88 & 98 \\
AUS & 1.45 & 1.21 & 1.34 & 1.51 & 1.45 & 1.31 & 1.28 & 1.34 & 1.08 & 1.22 \\
NZL & 1.89 & 1.62 & 1.83 & 1.83 & 1.77 & 1.92 & 1.83 & 1.98 & 1.82 & 2.00 \\
MEX & 11.0 & 8.0 & 8.3 & 9.1 & 10.4 & 11.5 & 11.8 & 12.0 & 11.9 & 12.1 \\
BRA & 1.97 & 1.97 & 1.86 & 2.05 & 1.86 & 1.67 & 1.47 & 1.56 & 1.83 & 2.02 \\
IDN & 6186 & 5304 & 5521 & 5019 & 5315 & 6195 & 6389 & 6332 & 7294 & 8064 \\
IND & 34.9 & 27.7 & 24.8 & 26.5 & 32.5 & 37.4 & 34.9 & 38.6 & 41.9 & 45.9 \\
KOR & 1026 & 831 & 859 & 878 & 816 & 877 & 857 & 802 & 748 & 832 \\
HKG & 6.14 & 5.84 & 5.76 & 5.56 & 5.35 & 4.98 & 5.07 & 4.68 & 4.05 & 4.70 \\
SGP & 1.31 & 1.17 & 1.16 & 1.11 & 1.31 & 1.18 & 1.08 & 1.09 & 1.09 & 1.22 \\
TWN & 28.11 & 22.59 & 20.74 & 21.35 & 25.35 & 24.36 & 23.28 & 23.28 & 22.45 & 25.03 \\
MYS & 2.86 & 2.53 & 2.33 & 2.23 & 2.40 & 2.35 & 2.23 & 2.22 & 1.96 & 2.15 \\
PHL & 37.6 & 40.8 & 36.6 & 33.3 & 29.0 & 33.9 & 36.8 & 27.1 & 21.9 & 24.2 \\
THA & 26.7 & 26.4 & 27.6 & 27.4 & 27.5 & 34.6 & 30.2 & 25.0 & 26.7 & 29.4 \\
CHN & 6.57 & 5.70 & 5.03 & 5.41 & 5.59 & 5.00 & 4.69 & 4.49 & 4.28 & 5.68 \\
\hline
\end{tabular}

${ }^{*}$ Targets for USA and China are set to -3 and +3 respectively. $+=$ undervaluation

Table A.3 - Gap to current account targets (\% of GDP)

\begin{tabular}{lcccccccccc}
\hline & USA & EUR & CAN & GBR & JPN & AUS & NZL & MEX & BRA & IDN \\
ACI & -0.05 & -0.07 & -0.55 & -0.33 & -0.21 & -0.98 & -6.84 & -0.60 & -0.63 & -2.44 \\
OCI & -0.30 & -0.26 & -0.13 & -0.24 & -0.49 & -0.81 & -0.37 & 0.01 & -0.11 & -0.43 \\
RM & -0.21 & -0.31 & -0.54 & -0.49 & -0.30 & -0.39 & -0.30 & -0.27 & -0.18 & -0.31 \\
MTG & -0.48 & -0.31 & -0.13 & -0.16 & -0.18 & -0.09 & -0.03 & -0.14 & -0.11 & -0.05 \\
ETG & -0.30 & -0.30 & -0.30 & -0.30 & -0.30 & -0.30 & -0.30 & -0.30 & -0.30 & -0.30 \\
\hline & IND & KOR & HKG & SGP & TWN & MYS & PHL & THA & CHN & ROW \\
ACI & -0.51 & -0.99 & -5.63 & -7.40 & -2.93 & -9.60 & -3.90 & -3.99 & -0.38 & -0.10 \\
OCI & -0.13 & -0.57 & -1.12 & -4.07 & -0.94 & -1.54 & -0.38 & -0.88 & -0.34 & -0.23 \\
RM & -0.20 & -0.46 & -1.29 & -1.56 & -0.63 & -0.98 & -0.29 & -0.62 & -0.43 & -0.31 \\
MTG & -0.15 & -0.09 & -0.03 & -0.03 & -0.05 & -0.02 & -0.05 & -0.04 & -0.11 & -0.26 \\
ETG & -0.30 & -0.30 & -0.30 & -0.30 & -0.30 & -0.30 & -0.30 & -0.30 & -0.30 & -0.30 \\
\hline
\end{tabular}

Note: The table presents the difference between the ex post current account (i.e. reached by estimated equilibrium exchange rates) and the target current account, for the different methods: MTG (minimize target gaps), ETG (equalize target gaps), Faruqee \& Isard's RM (readjustment of misalignments) and Cline's OCI (other countries included) and ACI (all countries included) methods (see Section 4.2). 